\title{
Video-based focus group for chemistry knowledge construction by secondary preservice teachers
}

\section{Rodríguez-Arteche, Iñigo ${ }^{a}$; Martínez-Aznar, M.Mercedes ${ }^{\mathrm{a}}$}

${ }^{a}$ Departamento de Didáctica de las Ciencias Experimentales, Universidad Complutense de Madrid, Spain

\begin{abstract}
The present work analyzes the relavance of using video for promoting reflection about chemical contents and their learning, in the context of the Spanish Master's in Secondary Education. The used video clips were edited from the recordings of two cooperative groups of Master's students who were solving an open-ended problem about chemistry. This problem was stated as follows: "What might happen when two substances are placed into contact with each other?» These clips contained some alternative conceptions in chemistry, together with some theoretical and practical difficulties arisen in the solving process. Later, the video was shown in the framework of a focus group, where a free debate between the participants was stimulated. The transcriptions of this session gave rise to a group of categories of analysis related to different stages of problem resolution, and emotional aspects as well. These results make us conclude that using video is an appropriate way of promoting learning about physical and chemical changes through cognitive conflict. Moreover, the necessity of considering emotional, individual and group aspects in conceptual change is supported.
\end{abstract}

Keywords: Video; focus group; problem-based learning (PBL); initial teacher training; alternative conceptions in chemistry; cognitive conflict. 


\section{Introduction and theoretical framework}

Nowadays there is a general consensus about the convenience of using problem-based learning methodologies (PBL) for overcoming the problem of lack of motivation in the subject of science, and promoting the students' reasoning skills (Abd-El-Khalick et al., 2004). This method has its origin in medical education programs in Canada in the 1970's (Savery, 2006). From then on, its use has been extended to other university studies and, in particular, to the educational ones (Hmelo-Silver, 2012). However, its application to other education levels has been less frequent, probably because of the difficulties which arise when implementing this methodology. In this sense, the main challenge is related to the revision of the traditional roles of both teachers and students in the learning process (the teacher acts as a guide and the students must be responsible for their own learning, defining by themselves what they need to know to solve complex problems) (Prince \& Felder, 2007). In order to overcome these issues, we believe that PBL methods should form an active part of teacher training programs, in order to favour a necessary update of scientific education. As such, 'explaining' the characteristics of these methodologies is not enough, but the training programs should provide science learning experiences through PBL methods.

Our 'PBL-choice' for the Spanish Master's in Secondary Education (MSE) -a requirement for working as a teacher in these levels- is the Methodology of Problem-Solving as an Investigation (MPSI), which is one of the main research lines of our group. Our previous studies about the MPSI gave us very good results in terms of the conceptual and procedural change of students (Ibáñez \& Martínez, 2005; Pavón \& Martínez, 2014), and showed the effectiveness of the method for increasing students' motivation in different contexts (Pavón \& Martínez, 2014).

The MPSI has five stages which resemble the ways of working of a novice researcher in a research team, in accordance with the scientific competencies of the educational curricula. These stages, which should be understood as s cyclical process, are explained in Table 1. One of the essential features of the MPSI (shared by all PBL methods) is that it is a studentcentered approach, since they have to regulate their knowledge construction (Pecore, 2013) by working in cooperative groups (English \& Kitsantas, 2013). For these reasons, we believe that using video with the intention of stimulating reflection about the students' problem-solving processes (either by themselves or by other students) can be a very beneficial tool. As such, it could help to promote conceptual knowledge construction through conflicts arisen from the interactions between students -where emotional aspects are relevant- (Pintrich et al., 1993). 
Table 1. Stages and characteristics of the Methodology of Problem-Solving as an Investigation (MPSI).

\begin{tabular}{ll}
\hline $\begin{array}{l}\text { Competence Dimension } \\
\text { (CD) / Stage }\end{array}$ & \multicolumn{1}{c}{ Some tasks implied in the stage } \\
\hline CD1: Qualitative analysis & $\begin{array}{l}\text { Understanding and representation of the problem } \\
\text { Reformulation of the problem (operative terms) / Restrictions }\end{array}$ \\
\hline $\begin{array}{l}\text { CD2: Formulation of } \\
\text { hypotheses }\end{array}$ & Formulation of conjectures to guide the problem-solving \\
\hline $\begin{array}{l}\text { CD3: Design of } \\
\text { resolution strategies }\end{array}$ & $\begin{array}{l}\text { Variable identification and control / Magnitudes, materials... } \\
\text { Decision-making for the resolution }\end{array}$ \\
\hline $\begin{array}{l}\text { CD4: Resolution of the } \\
\text { problem }\end{array}$ & $\begin{array}{l}\text { Carrying out the designs } \\
\text { Description of the process, observations, data... / Getting results }\end{array}$ \\
\hline CD5: Analysis of results & $\begin{array}{l}\text { Obtaining regularities } \\
\text { Reference to hypotheses and theoretical framework }\end{array}$ \\
\hline
\end{tabular}

\section{Objective}

The research question that guided this follow-up study was:

«¿Does the reflection arisen from a focus group with the projection of a video -where future teachers reveal some alternative conceptions- favour their chemistry knowledge construction?»

\section{Development of the reseach}

This descriptive and qualitative case study considers video as a tool for promoting reflection and conceptual change in chemistry.

The research took place in the Chemistry Education subject of the Master's in Secondary Education (MSE), corresponding to its 'physics and chemistry' specialization (school year 2013/14, Universidad Complutense de Madrid). In this subject, the students had to solve a series of professional problems such as content selection, design and implementation of learning activities and assessment of the educational process (Martínez et al., 2013). Concerning the analysis of the different kinds of learning activities, the MSE students were introduced to the MPSI - the previously described PBL methodology- (Ibáñez \& Martínez, 2005). With the goal of promoting a later use of the MPSI in secondary schools, the chemistry education subject provided learning opportunities through this methodology, and MSE students were asked to solve a proposed sequence of school chemistry open-ended 
problems, working in heterogeneous cooperative groups. In that way, future teachers could personally experience how learning through the MPSI takes place.

In this paper, we will consider the following experimental problem: 'What might happen when two substances are placed into contact with each other?' The problem deals with a fundamental content of secondary school chemistry, which is the distinction between physical and chemical changes. In order to develop the focus-group activity analyzed in Section 4, the problem-solving processes of two independent cooperative groups were recorded on video and audio, and latter transcribed. Then, a series of video segments about their resolution were selected and edited, considering both groups in an equitable way. The consensus of the two researchers was required for this edition process.

Finally, these video clips were shown to the implied MSE students, with the intention of promoting their reflection and knowledge construction (Martin \& Siry, 2012) -and from a research perspective, in order to test the usefulness of the clips-. The characteristics of the members of the two cooperative groups who took place in the activity are shown in Table 2 (description of the sample).

Table 2. Characteristics of the study sample. The cooperative groups require at least one chemistry graduate and one physics graduate.

\begin{tabular}{ccccc}
\hline Group & Student & Gender & Age & Initial studies \\
\hline \multirow{3}{*}{ Group 1 } & S1 & Female & 24 & Chemistry graduate \\
& S2 & Male & 26 & Physics graduate \\
& S3 & Male & 35 & Engineer \\
\hline \multirow{3}{*}{ Group 2 } & S4 & Male & 29 & Engineer \\
& S5 & Female & 30 & Physics graduate \\
& S6 & Male & 23 & Chemistry graduate \\
\hline
\end{tabular}

\subsection{Video segment considered for the present study}

In this paper we will focus on the future teachers' debate arisen from the view of 1 of the 9 video clips which were prepared for a focus group. In particular, the clip chosen for this article showed how the MSE students from the two groups expressed some alternative conceptions related to physical and chemical changes during the problem-solving. These alternative conceptions were the following ones: identifying distillation as a chemical change; considering that chemical substances react 'atom by atom', talking about 'physical reactions'; and considering the possibility of reverting a complete chemical reaction. The total length of time of the segment was about 1 minute. 


\subsection{Video-based focus group}

The previously mentioned video watching session was organized in the framework of a focus group, where the 6 students of Table 2 participated together. The focus group is a qualitative technique (set in the context of group interviews) which allows for knowing in depth the participants' reflections about the debated issue. As such, it has an advantage over other techniques, meaning that their opinions are not limited by the researchers' previous conceptions (Stewart et al., 2006).

The focus-group session had a total length of time of 50 minutes and it was also recorded on video and audio (there were 9 video clips in total). However, the participants' responses to the video segment described in Section 3.1 lasted about 7 minutes. The moderator (a member of the research team) was responsible for introducing the debate without intervening, but trying to create a climate of confidence. In addition, the moderator asked for precision when necessary, without expressing agreement or disagreement (Stewart et al., 2006).

\subsection{Data analysis techniques}

In order to analyze the verbal interactions in the focus group, the session was transcribed and divided into analysis units. Later, they were classified in categories, with the requirement of consensus between the two researchers. In this work we will consider as 'categories' what MSE students expressed about the 5 competence dimensions of the MPSI (its 5 stages of Table 1). Moreover, the sixth category corresponds to the future teachers' emotions, a dimension which is reasonable to consider because of the constructivist nature of PBL methods (Prince \& Felder, 2007). In all these cases, we will distinguish between direct reflections about their practical resolutions, and indirect reflections which arose from the focus group (not directly related to what they did in the laboratory).

\section{Results}

The view of the video clip about the students' own alternative conceptions promoted a debate of approximately 7 minutes. In order to have a picture of these interactions, Figure 1 connects the information units arisen to the previously described categories of analysis. These units are represented as a function of the time from the beginning of the debate. In addition, each student's reflections are represented with different colours (S1-S6 students from Table 2). Four out of the five competence dimensions of the MPSI appeared in the debate (all except the formulation of hypotheses, CD2), in addition to some future teachers' emotions. Moreover, Figure 1 shows that indirect reflections, marked with a letter $(i)$, were majority in the focus group ( $75 \%$ of the information units). 


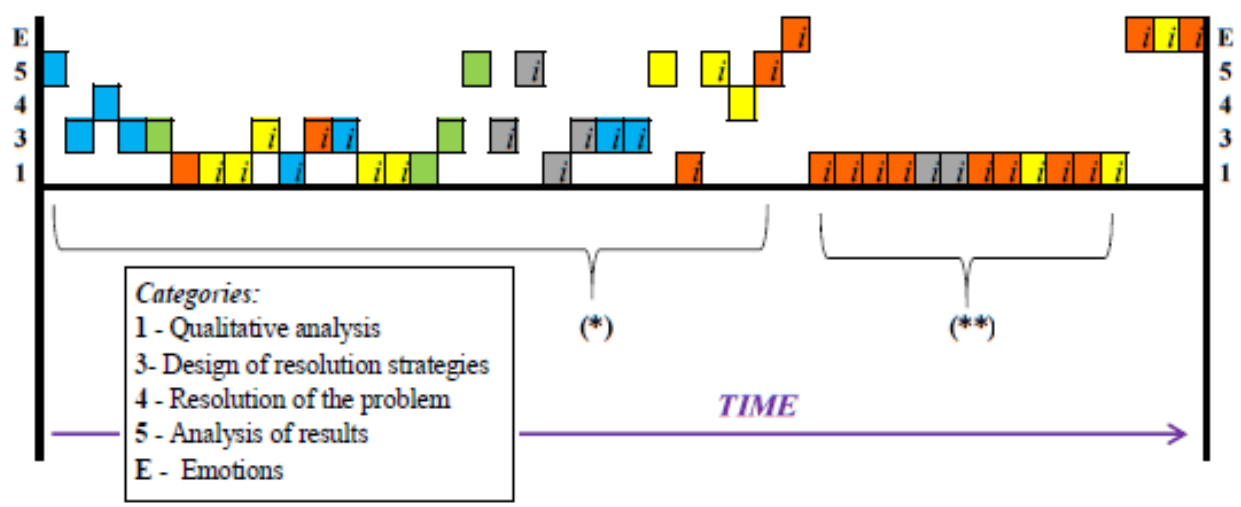

Figure 1. Categories for the information units as a function of time. Indirect reflections are indicated with " $i$ ". The corresponding students from the sample are: S1-orange, S2-yellow, S4-green, S5-blue, S6-grey (S3 did not make any reflection for this clip). The asterisks distinguish two parts of the debate, as explained in the text.

Figure 1 also suggests that the future teachers' reflections dealt with two main topics. In the first part of the debate -marked with (*)- the MSE students' discussed about how to distinguish physical and chemical changes, taking into account what they did in the laboratory. As such, by means of 11 direct statements and 17 indirect ones, future teachers reflected on their problem-solving process. In this way, some doubts arose about the theoretical framework and the resolution strategies, which gave rise to the addition of information in order to support their reasoning. Table 3 contains some examples of reflections on the different categories of analysis.

Table 3. Examples of future teachers' direct and indirect reflections in the first part of the debate, (*). The corresponding students S1-S6 are indicated.

\begin{tabular}{|c|c|}
\hline Category & Example of reflection \\
\hline $\begin{array}{l}\text { CD1, indirect: } \\
\text { theoretical framework to } \\
\text { distinguish physical and } \\
\text { chemical changes }\end{array}$ & $\begin{array}{l}\text { "I had always thought more in the properties: the changes in } \\
\text { solubility, colour... melting and boiling points... Well, don't } \\
\text { know... the reversibility and irreversibility [criterion] is not clear to } \\
\text { me." (S2, information unit \#13) }\end{array}$ \\
\hline $\begin{array}{l}\text { CD3, direct: laboratory- } \\
\text { strategies }\end{array}$ & $\begin{array}{l}\text { "During the whole [practical] process we didn't consider the } \\
\text { temperature variable." (S4, information unit \#16) }\end{array}$ \\
\hline $\begin{array}{l}\text { CD4, direct: practical } \\
\text { resolution of the problem }\end{array}$ & $\begin{array}{l}\text { "We had two [water] soluble substances, we placed them into } \\
\text { contact and we obtained a precipitate." ( } 2 \text { 2, information unit \#27) }\end{array}$ \\
\hline $\begin{array}{l}\text { CD5, indirect: analysis of } \\
\text { results, taking } \\
\text { information from the } \\
\text { debate }\end{array}$ & $\begin{array}{l}\text { "I see... You mean it is a [chemical] reaction, isn't it? (...) I think } \\
\text { there's no need for other [mentioned] studies." (S1, information unit } \\
\# 28)\end{array}$ \\
\hline
\end{tabular}


On the other hand, starting from an emotional reflection where S1 said "I'm completely confused" -reflection number 29 in Figure 1-, she began to question that a chemical reaction could take place in a non-aqueous medium. Due to her contribution, another phase of the debate began, marked with (**). Here, S1 talked about the necessity of rearrangement of the ions for producing a chemical reaction, and also compared the physical changes of 'dissolving' and 'melting'. These arguments gave rise to a variety of indirect reflections about the theoretical framework of the problem, where opposing understanding of the concepts where found, as can be seen in Table 4.

Table 4. Examples of future teachers' indirect reflections in the second part of the debate, $\left({ }^{* *}\right)$. The corresponding students S1-S6 are indicated.

\begin{tabular}{lll}
\hline \multicolumn{2}{c}{ Category } & \multicolumn{1}{c}{ Example of reflection } \\
\hline $\begin{array}{l}\text { CD1, } \\
\text { understanding } \\
\text { melting process }\end{array}$ & of the & $\begin{array}{l}\text { "If you melt a substance, you don't separate the charges [it is } \\
\text { different from 'dissolving']." (S6, information unit \#35) }\end{array}$ \\
\hline $\begin{array}{l}\text { CD1, } \\
\text { understanding } \\
\text { melting process }\end{array}$ & indirect: & "You do separate the charges [in a melting process]. This is why \\
[salts] are conductors in liquid state." (S1, information unit \#36)
\end{tabular}

Finally, the debate arisen from the video segment ended with some other emotional statements. This fact reveals that a teacher should not ignore students' emotional and affective aspects, since they may limit conceptual change (Duit \& Treagust, 2003).

\section{Conclusions}

The study carried out has allowed us to test the effectiveness of a video-based technique in order to promote chemistry knowledge construction. As such, although some alternative conceptions shown in the video segment were not identified by preservice teachers, the debate between the participants gave rise to cognitive conflicts on the topic (e.g., about inter- and intramolecular forces, see Table 4). Moreover, the fact that most of the reflections were indirect ones tells us about the potentiality of the technique (the information that can be obtained is not limited by the researchers' beliefs). The analyzed results also suggest that emotional and group aspects play an important role in this process.

Finally, it is worth emphasising that the obtained video segment seems to be a useful resource for physics and chemistry teacher training programs. It is our plan to use it in the future, not only for analyzing preservice teachers' own resolutions, but also for assessing other students' problem-solving processes. 


\section{References}

Abd-El-Khalick, F., Boujaoude, S., Duschl, R., Lederman, N.G., Mamlok-Naaman, R., Hofstein, A., Niaz, M., Treagust, D. \& Tuan, H-L. (2004). Inquiry in Science Education: International perspectives. Science Education, 88, 397-419.

Duit, R. \& Treagust, D. F. (2003). Conceptual change: a powerful framework for improving science teaching and learning. International Journal of Science Education, 25(6), 671688.

English, M.C. \& Kitsantas, A. (2013). Supporting student self-regulated learning in problem- and project-based learning. Interdisciplinary Journal of Problem-Based Learning, 7(2), 128-150.

Hmelo-Silver, C.E. (2012). International perspectives on problem-based learning: contexts, cultures, challenges, and adaptations. Interdisciplinary Journal of Problem-Based Learning, (1), 10-15.

Ibáñez, M.T. \& Martínez-Aznar (2005). Solving problems in genetics (II): Conceptual restructuring. International Journal of Science Education, 27(12), 1495-1519.

Martin, S.N. \& Siry, C. (2012). Using video in science teacher education: an analysis of the utilization of video-based media by teacher educators and researchers. In Fraser, B.J., Tobin, K.G. \& McRobbie, C.J. (Eds.), Second International Handbook of Science Education, vol. 1 (pp. 417-433). New York: Springer.

Martínez-Aznar, M.M., Varela, P., Ezquerra, A. \& Sotres, F. (2013). Las Unidades Didácticas escolares, basadas en competencias, como eje estructurante de la Didáctica de la Física y Didáctica de la Química para la formación inicial de profesores de secundaria. Revista Eureka sobre Enseñanza y Divulgación de las Ciencias, 10, 616629.

Pavón, F. \& Martínez-Aznar, M.M. (2014). La metodología de resolución de problemas como investigación (MRPI): una propuesta indagativa para desarrollar la competencia científica en alumnos que cursan un programa de diversificación. Enseñanza de las Ciencias, 32(3), 469-492.

Pecore, J.L. (2013). Beyond beliefs: teachers adapting problem-based learning to preexisting systems of practice. Interdisciplinary Journal of Problem-Based Learning, (2), 7-33.

Prince, M.J. and Felder, R.M. (2007). The many faces of inductive teaching and learning. Journal of College Science Teaching, 36(5), 14-20.

Printrich, P.R., Marx, R.W. \& Boyle, R.A. (1993). Beyond cold conceptual change: The role of motivational beliefs and classroom contextual factors in tehe procces of conceptual change. Review of Educational Research, 63, 167-199.

Savery, J.R. (2006). Overview of Problem-based Learning: Definitions and Distinctions. Interdisciplinary Journal of Problem-Based Learning, 1(1), 5-15.

Stewart, D.W., Shamdasani, P.N. \& Rook, D.W. (2006). Focus Groups: Theory and Practice. Thousand Oaks: SAGE publications. 